\title{
Keindahan Versus Narsisme dalam Undangan Pernikahan
}

\author{
Maria Nala Damayanti \\ Jurusan Desain Komunikasi Viasual, Fakultas Seni dan Desain \\ Universitas Kristen Petra \\ Email: mayadki@petra.ac.id
}

\begin{abstract}
Abstrak
Salah satu produk desain grafis yang cukup popular di masyarakat adalah undangan pernikahan karena umumnya orang yang akan melangsungkan pernikahan membuat undangan. Undangan biasanya dicetak dalam jumlah tertentu dan dikirim kepada kerabat serta teman ke berbagai penjuru kota bahkan negeri. Akhir-akhir ini sering dijumpai model undangan pernikahan yang dihiasi oleh foto calon pengantin. Berbagai pose dan gaya keakraban pasangan calon pengantin yang tadinya adalah milik personal kemudian menyebar dan menjadi milik publik. Undangan akhirnya berfungsi juga sebagai media 'pamer' atau 'iklan' diri. Dalam psikologi perkembangan, individu dengan kecenderungan suka pamer diri disebut sebagai salah satu kelainan kepribadian yang dikenal dengan nama narsis. Apakah undangan dengan kecenderungan gaya desain seperti dijelaskan diatas dapat dikatakan sebagai salah satu bentuk narsisme. Topik ini akan diteliti lebih jauh dengan tinjauan menurut psikologi sosial. Pada sisi lain, wujud desain semacam ini dapat mencerminkan minat konsumen terhadap keindahan undangan pernikahan. Sejauh mana hal-hal di atas saling berkaitan, akan ditelaah dalam tulisan ini.
\end{abstract}

Kata kunci: Undangan pernikahan, narsisme, foto pra nikah.

\begin{abstract}
One type of graphic design product that is quite popular in the community is a wedding invitation, because generally people who get married make them. Invitations are usually printed at a certain amount and sent to relatives and friends to various parts of the city and even the country. Lately models of wedding invitations decorated by the bride and groom photos are frequently encountered. A variety of poses and styles of the couple's intimacy that have been personal property then spread and become publicly owned. Invitations ultimately serve also as a 'show off' or 'advertising' media. In developmental psychology, the tendency of individuals to ostentatiously self exhibit is a personality disorder known as narcissistic. Is the trend of stylish invitation designs as described above can be regarded as a form of narcissism will be questioned. This topic will be further investigated by a review by social psychology. On the other hand, this kind of design can reflect the interests of consumers towards the beauty of wedding invitations. The extent to which these things are related, will be explored in this paper.
\end{abstract}

Keywords: Wedding invitations, narcissism, pre-wedding photography.

\section{Undangan Sebagai Media Komunikasi}

Undangan pernikahan adalah salah satu produk desain grafis yang merupakan representasi kompleks dari sub-sub sosial budaya, yang dalam perkembangannya menjadi sebuah fenomena sendiri sebagai hasil pertautan konsep nilai, materi, yang dapat diamati sevcara visual (Damayanti 20). Secara fisik undangan pernikahan berbentuk lembaran kertas yang merupakan hasil cetakan berisi teks verbal dan teks non verbal atau visual. Umumnya undangan pernikahan terdiri dari dua bagian utama yang meliputi amplop yang bertuliskan nama dan alamat penerima serta pengirim dan isi yaitu inti undangan itu sendiri. Dalam perkembangannya terdapat penambahan halaman isi serta perubahan bentuk. Proses pembuatan undangan melibatkan setidaknya tiga pihak yakni calon pengantin sebagai klien dan desainer sebagai perancang visual dan percetakan yang berfungsi memperbanyak desain. Dari sisi isi, undangan dapat dibagi ke dalam dua bagian besar yaitu:

\section{Teks Verbal}

Teks verbal yang ada pada undangan biasanya merupakan hasil keputusan bersama dari pihak- 
pihak yang terlibat dalam pernikahan. Teks verbal yang dimaksud disini adalah susunan huruf (tipografi) atau tulisan yang terdapat pada undangan. Tulisan utama daripada undangan terbagi ke dalam beberapa bagian besar antara lain: kata pembuka (kadang berupa doa dan harapan), nama mempelai pria dan wanita (terkadang dilengkapi gelar pendidikan), nama orang tua mempelai, informasi resepsi (tanggal, alamat dan tempat pernikahan), dan kata penutup (ucapan terimakasih). Teks verbal yang tersebut di atas seringkali masih mengalami penambahan yang sangat tergantung pada prioritas dan kepentingan yang bersifat pribadi.

\section{Teks Visual}

Teks visual adalah tampilan akhir yang dapat diamati, yang mana dalam hal ini dipisahkan dari pembahasan teks verbal. Teks visual terdiri dari segala sesuatu yang dapat diamati secara fisik selain verbal yaitu bentuk undangan, warna undangan, elemen hias, foto dan atau gambar pasangan pengantin. Secara visual tersurat corak dan latar belakang budaya dari calon pengantin yang muncul berupa motif pada pakaian atau elemen hias yang menyebar pada halaman undangan. Tentang latar belakang sosial atau budaya lebih jelas tampak pada gambar atau foto calon pengantin yang akhir-akhir ini selalu muncul di banyak undangan pernikahan. Melalui pakaian yang dikenakan dapat diduga dari mana calon pengantin berasal. Pose dan aksi mereka seperti layaknya foto model.

Visual akhir undangan ini biasanya merupakan hasil pembicaraan antara calon pengantin dengan pihak desainer yang bertanggung jawab mewujudkan desain sebagaimana kesan yang diharapkan oleh klien. Tampilan atau desain undangan biasanya memperlihatkan gaya desain tertentu yang khas. Ada sentuhan pribadi yang senantiasa dimunculkan sebagai identitas. Artinya melalui kombinasi dan komposisi teks verbal dan teks visual ini bisa teramati penerapan desain sebagai kesatuan dari berbagai elemen pada undangan, dengan fungsi formalnya adalah media yang mengkomunikasikan sebuah acara.

\section{Representasi dan Makna Undangan}

Berbicara mengenai representasi, menurut Thwaites (2002:1), selalu akan menyinggung kebudayaan, yang berarti sekumpulan praktek sosial yang melaluinya makna diproduksi, disirkulasi, dan dipertukarkan. Yang bagi J.J. Hoenigman, wujud kebudayaan itu bisa dibedakan menjadi tiga yaitu gagasan, aktivitas, dan artefak (34-39). Sedangkan istilah representasi menurut Stuart Hall, berarti menggunakan bahasa untuk menyampaikan sesuatu yang penuh arti atau bermakna kepada orang lain. Juga dikatakan bahwa representasi adalah produksi makna melalui bahasa dan memegang peranan penting dalam memproduksi kebudayaan. Bahasa disini dapat berupa bahasa verbal atau bahasa non verbal untuk mengkomunikasikan pesan yang ingin disampaikan. Kebudayaan menyangkut pengalaman berbagi dalam suatu kelompok masyarakat. Seseorang dikatakan berasal dari kebudayaan yang sama jika manusia-manusia yang ada saling berbagi pengalaman, kode, bahasa dan konsep yang sama. (Hall, 2002). Pendekatan kebudayaan ini dalam antropologi dikenal sebagai pendekatan struktural, dimana pelbagai fenomena kebudayaan dibaca sebagai bahasa atau sistem tanda untuk berkomunikasi.

Dalam studi budaya undanganpun dapat disebut sebagai 'tanda' yang diartikan sebagai apapun yang memproduksi makna. Bila sebuah undangan dilihat sebagai suatu 'tanda', maka banyaklah makna terkandung disana. Makna tersebut bergantung pada beragam faktor termasuk situasi dan konvensi dimana tanda tersebut digunakan, jadi bergantung pada apa yang mengitarinya. (Thwaites, 2002, dan Eco,1994 dalam Sachari, 2005:66).

Sehubungan pengertian di atas dan pamahaman bahwa undangan pernikahan adalah sebuah produk budaya yang dapat dilihat sebagai 'tanda' maka undangan pernikahan memiliki arti lebih dari sekedar lembaran kertas penyampai berita pernikahan. Konsep undangan sangatlah penting karena selain menyampaikan kabar pernikahan, undangan pernikahan juga memberikan kesan tertentu kepada penerima undangan. Selanjutnya bisa dipahami juga bahwa ada serangkaian harapan yang coba dibangun dan dicitrakan melalui undangan. Sebuah karya desain yang melambangkan citra serta mencerminkan status bagi si pengundang. Jadi seluruh elemen yang membangun undangan adalah sekumpulan 'tanda' yang dapat dilihat sebagai representasi kebudayaan yang penuh makna. Dyer menyebutkan empat bentuk representasi bagaimana detail visual dapat menyampaikan tanda bermakna, yaitu representation of body (umur, gender, rambut, tubuh, ukuran, penampilan), representation of manner (ekpresi, eye contact, pose), representation of activity (sentuhan, gerak tubuh, komunikasi posisi), props \& setting ( properti, setting). (Rose, 2001:77) 


\section{Media dan Perubahan Sosial dalam Masyarakat Modern}

Penggunaan media komunikasi telah menciptakan bentuk baru dari tindakan (aksi) dan interaksi dalam dunia modern. Peran media dapat mendorong dan menghidupkan tindakan kolektif dari individu meskipun dalam jarak yang berjauhan. Contohnya seperti perayaan yang dilakukan oleh sekelompok orang di banyak negara sehubungan dengan sebuah peristiwa yang terjadi di suatu tempat bahkan yang terpencil sekalipun. Contoh nyata seperti yang terjadi pada peristiwa runtuhnya tembok Berlin dan peristiwa pemilihan presiden Amerika Barrack Obama. Media mampu membangun image dan membuat ketersediaan informasi untuk orang yang berjauhan. Media memberi bentuk dan mempengaruhi bentuk dari kegiatan dan interaksi. Ini sangat berbeda dari peranan media di masa lalu, yang lebih berfungsi pelaporan yang bersifat searah. Cohen dalam Wall Sreet Journal menyebutkan pengaruh media terhadap kehidupan masyarakat saat ini sangat kuat dibanding 50 tahun yang lalu. (Cohen, Dec 1. 2007)

Jarak tidak menghalangi bentuk interaksi kolektif, bahkan melalui media semua itu seperti terhubung bahkan timbal balik secara aktif, yang pada gilirannya ikut menyusun perubahan sosial. Maka sangat mungkin individu secara personal melakukan tindakan memproduksi informasi dan individu lain yang menerima bertindak sebagaimana informasi yang mereka terima. Pelakupelaku media sendiri sangat menyadari peranan media sehingga seringkali dikontrol sedemikian rupa untuk membawa keuntungan bagi mereka yang berkepentingan. Namun teknologi informasi dan saluran komunikasi yang demikian canggih telah menyumbang secara signifikan pada kekompleks-an dunia komunikasi karena interaksi yang terjadi sangat cepat, dramatis, bahkan dengan cara yang tidak terprediksi sebelumnya (Thompson, 1995)

\section{Narsis, Narsistik}

Kata narsis atau narcissm berangkat dari terminologi Freud, dimana seseorang terobsesi akan dirinya sendiri. Menurut buku Pedoman Penggolongan Diagnosa Gangguan Jiwa di Indonesia (PPDGJ, 1983) dan Diagnostic Statistical Manual of Mental Disorders (DSM-IV-TR, 2004) ada tiga belas gangguan kepribadian anti sosial, salah satunya adalah gangguan kepribadian narsistik. Orang dengan kepribadian narsistik ditandai oleh meningkatnya rasa kepentingan diri dan perasan kebesaran yang unik. Gangguan kepribadian ini bisa menjadi epidemiologi karena kasus klinisnya terus meningkat secara mantap (Kaplan dan Saddock, 1996). Penderitanya dikatakan kronis dan sukar diobati. Dalam psikolanalisis, narsis normal terjadi pada masa kanak-kanak. Pada orang dewasa atau setelah masa pubertas disebut sebagai narsis kedua. Tingkatan narsistik dikatakan normal bila seseorang memiliki cukup penghargaan atas diri sendiri dengan aspirasi yang realistis. Dikatakan mengalami gangguan (personality disorder) apabila kondisi tersebut berulang, menetap dan menjadi karakter yang dapat ditelusuri dalam suatu jangka waktu tertentu dan secara patologis (oleh psikologi klinis/psikiatris) dinyatakan telah mengganggu fungsi sosial seseorang. Orang dengan gangguan kepribadian narsistik cenderung mengagumi diri sendiri secara berlebihan atas keunikannya, atas kesuksesannya, atas atribut sosialnya, dan ia senantiasa membutuhkan penghargaan dari orang lain untuk kenyamanannya dan untuk memperkuat keyakinan akan dirinya sendiri. Seorang narsistik cenderung memiliki masalah dalam berhubungan dengan orang lain dalam lingkungan sosialnya.

American Psychiatric Association (2000:717) dalam Cognitive Theraphy of Personality Disorder, menyebutkan tujuh kriteria orang dengan kepribadian narsistik antara lain menganggap diri mereka sangat penting, mengharap dikenal orang sebagai orang hebat meskipun tanpa prestasi, dipenuhi oleh fantasi kesuksesan, kekuasaan, kepandaian, kecantikan atau cinta yang ideal, percaya bahwa mereka orang yang special dan unik yang hanya dapat dimengerti atau harus disamakan dengan orang lain yang berstatus tinggi di atas mereka, membutuhkan kekaguman yang berlebihan, pengharapan yang tidak beralasan, mencari keuntungan diri melalui ekploitasi terhadap orang lain, sulit berempati, sering merasa iri terhadap orang lain, menunjukkan kesombongan, menunjukan sikap atau perilaku nakal. (Beck, 2007) Dari sejumlah pengertian ini maka dapat ditarik kesimpulan bahwa seorang mengalami gangguan kepribadian narsistik apabila perilakunya telah menggangu fungsifungsi sosial orang tersebut. Berikut tabel Kriteria Diagnostic gangguan kepribadian: 
Tabel 1. DSM-IV, Diagnostic and Statistical Manual of Mental Disorder, ed4. Hak Cipta American Psychiatric Association, Washington, 1994.

Pola pervasive kebesaran (dalam khayalan atau perilaku) membutuhkan kebanggaan, dan tidak ada empati, dimulai pada awal masa dewasa dan tampak dalam berbagai konteks seperti yang ditunjukkan oleh lima (atau lebih) berikut:

1. Memiliki rasa kepentingan diri yang besar (misalnya, pencapaian dan bakat yang dilebih-lebihkan, berharap terkenal sebagai superior tanpa usaha yang sepadan)

2. Preokupasi dengan khayalan akan keberhasilan, kekuatan, kecerdasan, kecantikan, atau cinta ideal yang tidak terbatas.

3. Yakin bahwa ia adalah "khusus" dan unik dan dapat dimengerti hanya oleh, atau harus berhubungan dengan, orang lain (atau institusi) yang khusus atau memiliki status tinggi.

4. Membutuhkan kebanggan yang berlebihan

5. Memiliki parasaan bernama besar, yaitu, harapan yang tidak beralasan akan perlakuan khusus atau kepatuhan otomatis sesuai harapannya.

6. Eksploitatif secara interpersonal, yaitu, mengambil keuntungan dari orang lain untuk mencapai tujuannya sendiri.

7. Tidak memiliki empati: tidak mau mengenali atau mengetahui perasaan dan kebutuhan orang lain.

8. Sering merasa iri dengan orang lain atau yakin bahwa orang lain iri kepada dirinya

9. Menunjukkan perilaku atau sikap yang congkak dan sombong

Sumber: Sinopsis Psikiatri, Kaplan dan Saddock, edisi kedua jilid dua

Tabel di atas memperlihatkan kriteria yang jelas bahwa gejala perilaku narsis setidaknya ditunjukkan oleh 5 ciri-ciri. Fakta lain akhir-akhir ini adalah orang awam sering menggunakan istilah tersebut berdasarkan perilaku seseorang bilamana menunjukkan salah satu dari ciri-ciri tersebut.

Dalam metodologi visual dikenal terminologi psikoanalisis Lacanian yang menyebutkan dua hasrat narsistik yaitu hasrat narsistik pasif simbolik yaitu hasrat untuk menjadi yang lain lewat pengenalan akan si subyek yang ditampilkan dan hasrat narsistik aktif simbolis yaitu hasrat untuk mengidentifikasi diri dengan yang lain sampai sejauh mana subyek tersebut bisa memanifestasikan penanda-penanda tertentu yang membawa kenyamanan narsistik. Misalkan saat seseorang dianggap tidak beradab maka ia akan mengejar penanda utama atau ego ideal yang beradab supaya ia dikatakan demikian, seperti sopan santun, moral, pendidikan dan seterusnya.
Menurut Lacan individu punya kecenderungan untuk mengidentifikasi diri dengan diri-diri ideal, serta keyakinan akan kebenaran hasrat bahwa dirinya sendiri adalah obyek. Lebih jauh lagi teori psikoanalisis Freud dalam buku Fashion Sebagai Komunikasi yang berhubungan dengan kesenangan (pleasure) dan hasrat (desire) menyatakan kebanyakan manusia normal memiliki hasrat untuk memandang dan memperoleh kesenangan lewat pandangan atas segala hal yang mereka jumpai yang menarik secara seksual (Barnard, 2006:164).

Penggunaan istilah narsis dalam semiotika visual tidak diketahui persis siapa yang memulainya. Tetapi istilah ini pernah digunakan oleh Dyer ketika menjelaskan makna tanda pada penjelasan representasi tubuh manusia yaitu tentang arti tatanan rambut wanita yang bisa merepresentasi kecantikan menggairahkan atau narsis. (lihat Dyer 1982:96-104 dalam Rose 2001:75)

\section{Perilaku sosial, Imitasi dan Fenomena Narsis}

Ranah psikologi sosial mengenal pendekatan belajar yang menekankan bahwa perilaku ditentukan oleh apa yang telah dipelajari sebelumnya dengan beberapa mekanisme. Ada dua mekanisme yang relevan dengan topik ini yaitu reinforcement dan imitasi. Mekanisme reinforcement yaitu seorang berperilaku tertentu karena perilaku itu disertai dengan sesuatu yang menyenangkan dan dapat memuaskan kebutuhan. Sedangkan mekanisme imitasi adalah seseorang mempelajari sikap dan perilaku sosial dengan meniru sikap dan perilaku seseorang lain yang menjadi model. (Sears, 1988:12-13) Berdasarkan teori ini dapat dipahami suatu kondisi pendekatan periklanan pada iklan-iklan tahun 1980-1990. Pada iklaniklan tersebut tampil foto model pria yang trampil dan rajin merawat tubuh dengan menggunakan kosmetik khusus untuk pria (namun tidak kewanita-wanitaan), sehingga menarik perhatian wanita (male gaze). Dulu hanya wanita yang bersolek untuk menarik perhatian pria (female gaze). Kini akibat bom bardir informasi yang disajikan media sedemikian rupa maka tidak heran selain wanita para priapun, terutama yang berada di wilayah perkotaan terpengaruh dan senang tampil bak foto model yang kerap muncul di media cetak maupun media elektronik (pria metroseksual). Sekarang ini hal bersolek tidak hanya milik wanita tetapi juga milik pria.

Pada sisi lain akhir-akhir ini cukup banyak artikel yang menulis tentang fenomena narsistik pada media komunikasi seperti pada situs jejaring sosial 
seperti facebook dan twitter. Pada kedua situs ini orang tampak sangat nyaman menampilkan foto dan menulis segala hal tentang mereka sekalipun merupakan informasi bersifat pribadi untuk menjadi konsumsi publik. (http://ulasingkat. blogspot.com, http://www.thefreelibrary. com/Twitter +narcissism).

Bisa jadi perilaku ini diperkuat oleh perilaku sebelumnya yang menimbulkan rasa senang atau akibat imitasi terhadap seseorang yang menjadi model (role model). Berdasarkan fakta yang telah dikemukakan, patutlah diduga bahwa inilah yang memperkuat pesan narsis yang muncul pada media pertemanan sosial. Kesukaan untuk dinikmati oleh orang lain demi memperkuat citra diri mengakibatkan orang-orang memproklamasikan sisi kehidupan pribadi mereka melalui media komunikasi yang paling mungkin, atau paling mudah diakses publik. Rupanya hal tersebut juga menggejala pada bentuk komunikasi lain seperti media cetak seperti yang belakangan ini mudah ditemui di pinggir-pinggir jalan di kota Surabaya berupa iklan promosi diri atau personal branding untuk kepentingan politik. Melalui interview yang dilakukan penulis, diperoleh komentar bernada sama yaitu terjadi narsisme pada undangan pernikahan yang ditampakkan antara lain melalui foto pasangan pengantin (pre-wedding) pada undangan pernikahan.

\section{Diskusi Dan Kesimpulan}

Memperhatikan kecenderungan desain undangan saat ini seperti pada sampel terkumpul, tampak ada kemiripan dengan media iklan pada sisi komunikasi, namun tidak pada sisi komersialnya. Pada undangan sebagai media komunikasi, terdapat subyek berkepentingan sekaligus obyek, yakni pengantin sebagai pengundang atau subyek, sekaligus sebagai obyek, terdapat audience yaitu tamu undangan, maka bisa dianalisis lebih lanjut dengan beberapa pendekatan metodologi visual menurut Berger dalam Semiotika Komunikasi (Sobur, 2003:117) dan Gillian Rose dalam Visual Methodologies (Rose, 2001) antara lain 1). Penanda dan petanda yang membangunnya dan 2). Fenomena sosiologis-demografi. Penanda adalah elemen pada undangan itu seperti bentuknya, desainnya (teks verbal dan teks visual), sendiri termasuk gambar/foto calon pengantin yang lazim disebut foto pre-wedding. Sedangkan petanda adalah konsep yang terbangun atas penandapenanda yang ada dan bersifat historis (Thwaites, 2002). Bila dikaitkan dengan fenomena sosiologisdemografi dimana terdapat sistem relasi yang memberinya nilai, kita dapat menangkap makna yang lebih luas dan dalam. Undangan memper- lihatkan status sosial subyek, salah satunya melalui mahal tidaknya harga cetak undangan. Berbagai teknik cetak baru diterapkan pada undangan pernikahan yang berdampak pada makin mahalnya harga undangan. Status sosial juga dapat diamati melalui tingkat pendidikan berupa gelar yang tertera. Selera seni dan gaya hidup calon pengantin melalui gaya desain undangan dan pose atau aksi dalam gambar/foto calon pengantin menunjukkan dari kelompok mana mereka berasal. Dari sampel ditemukan ciri kelompok urban yang teramati antara lain dari tampilan laki-laki dan perempuan yang sangat mirip dengan apa yang ditampilkan media iklan majalah atau televisi. Perlengkapan dan asesoris yang dipakai sebagai latar serta elemen grafis yang menghisasi undangan seperti sulur-sulur, elemen gambar hi-tech, dan lain-lain, bisa menunjukkan hobi, profesi atau gaya keseharian si subyek. Pakaian model baru atau klasik dengan sentuhan modern yang dikenakan, tampilan pria berdandan, dan aksi mereka seperti foto model menunjukkan simbol kekinian. Juga ditemukan beberapa pose foto favorit seperti pria berdiri merangkul wanita duduk, bergandengan tangan, bertatapan, dan lain-lain. (Hal ini bisa menjadi topik khusus diskusi terkait dengan sisten nilai yang dianut oleh kelompok sosial kaum urban). Namun demikian, tulisan ini tidak akan membahas lebih jauh menyangkut representasi tubuh, representasi manner, representasi activity, atau representasi property dan setting untuk memfokus pada gejala umum pada masyarakat.

Keindahan yang dimaksud pada judul tulisan lebih melihat pada gaya desain yang dipilih oleh pasangan menikah. Melalui observasi dan wawancara ditemukan bahwa kesadaran akan desain undangan pada masyarakat Surabaya menunjukkan selera gaya modern atau klasik modern. Tetapi eksekusi desain juga dipengaruhi oleh perancang grafisnya. Berdasarkan beberapa wawancara dengan subyek, ditemukan alasan penggunaan berbagai macam teknologi cetak dan pendekatan fotografi pre-wedd yang diduga representasi narsis, ternyata lebih disebabkan alasan tren visual masa kini dan keingingan aktualisasi diri.

Pada sisi lain ketika penulis mencoba mengaitkan dengan aspek ukuran foto pasangan pengantin (penonjolan) dan tingkat keseringan muncul dalam undangan, dengan luasnya penyebaran undangan maka jelas terlihat unsur-unsur narsis. Undangan seringkali menonjolkan subyek pengantin, yang bisa diduga berasal dari rasa keunikan atas diri dan rasa kebanggaan atas diri yang sebenarnya tidak berkaitan langsung dengan fungsi formal undangan itu sendiri. 
Penggunaan istilah narsis ternyata lebih dikarenakan munculnya gejala narsis yang tampak secara visual sebagai sebuah kecenderungan desain. Kondisi ini bisa dipahami sebagai akibat kemajuan teknologi komputer termasuk fotografi dan teknologi cetak selain teknologi informasi dan media komunikasi, sehingga terbentuk imitasi (role model) dengan mudah, hingga akhirnya menjadi perilaku banyak orang. Menurut beberapa pelaku pria alasan pemasangan gambar/ foto pre-wedd lebih karena dorongan atau keinginan pihak wanita. Tetapi penulis beranggapan kondisi ini jadi subur oleh sebab imitasi yang terjadi akibat peran media. Sehingga kini masyarakat tidak merasa aneh lagi bila melihat pria dan wanita berpose seperti foto model pada foto-foto pre-wedd. Sebaliknya justru tampak menyenangkan. Pada beberapa wanita lain alasan utama memasang gambar/foto pre-wedd pada undangan pernikahan adalah karena semua orang melakukan hal tersebut, sehingga kurang afdol bila mereka tidak melakukan hal yang sama. Alasan ini mungkin merupakan wujud hasrat narsistik pasif dan aktif simbolis sebagaimana dikemukakan Lacanian, dan dalam rangka pemenuhan pleasure dan desire seperti yang dikemukakan Freud. Tetapi temuan ini tidak bisa digeneralisir karena penulis tidak memakai metode wawancara sebagai sumber data utama.

Penelusuran lebih jauh terhadap faktor pendorong kecenderungan desain undangan seperti ini, bila bisa dikatakan fenomena, dapat diduga antara lain karena dalam dunia modern bahkan postmodern, batas teritori atau wilayah negara menjadi tidak ada akibat teknologi media komunikasi yang sangat modern dan canggih. Surabaya tentu saja tidak terlepas dari kemajuan tersebut. Maka perilaku memajang gambar/foto pre-wedd pada undangan bisa saja menunjukkan gejala narsis, tetapi bisa jadi adalah perilaku imitasi yang sangat dominan dipengaruhi oleh peran media, seperti alasan tren visual yang dikemukakan oleh beberapa subyek pelaku.

Beberapa kesimpulan dan saran dapat ditarik berdasarkan diskusi di atas, sebagai berikut:

1. Pendekatan visual yang berwujud pemasangan foto calon pengantin pada undangan pernikahan menunjukkan kecenderungan selera desain konsumen.

2. Faktor pendorong munculnya kecenderungan pemajangan foto calon pengantin ini adalah adanya perubahan nilai sosial kemasyarakatan yang berkaitan langsung dengan kemajuan teknologi komputer, termasuk fotografi dan teknologi cetak selain kemajuan teknologi komunikasi dan informasi, dan hal-hal ini memiliki hubungan timbal balik yang saling mempengaruhi.
3. Sikap memajang foto calon pengantin pada undangan pernikahan, bisa dikatakan mendekati salah satu gejala narsistik, tetapi tidak dalam pengertian mengalami kelainan kepribadian (personality disorder).

4. Dibutuhkan penelitian lebih lanjut apakah gejala yang sama juga terjadi pada masyarakat desa dengan kondisi sosial budaya yang berbeda dari masyarakat kota.

\section{Daftar Pustaka}

Barnard, Malcolm, (2006). Fashion Sebagai Komunikasi. Yogyakarta \& Bandung: Jalasutra.

Beck, Aaron T. dkk., (2007). Cognitive Therapy of Personality Disorder. New York \& London: Guilford Press.

Budiman, Kris, (2004). Jejaring Tanda-tanda, Strukturalisme dan Semiotic dalam Kritik Kebudayaan. Magelang: Indonesiatera.

Cohen, Adam., (2007, December 12). Europe Sees Society in Decline. Wall Street Journal (Eastern Edition), p. B.3D. Retrieved March 19, 2010, from ABI/INFORM Global. (Document ID: 1397084621).

Dyer, G., (1982). Advertising as Communication. London : Methuen.

Hall, Stuart, (2002). Representation. London : Sage Publication.

Heller, Stephen \& Chwast, Seymour, (1988). Graphic Style. London: Thames and Hudson.

Kaplan, Harold I. dkk., (1997). Sinopsis Psikiatri. Imu Pengetahuan Perilaku. Jakarta: Binarupa Aksara.

Damayanti, Maria Nala (2009). Gaya Desain Pada Visualisasi Undangan Pernikahan di Surabaya. Jurnal NIrmana, 11(1), 19-32.

Rose, Gillian. (2001). Visual Methodologies. London: Sage Publication.

Sachari, Agus, (2004). Pengantar Metode Penelitian. Budaya Rupa. Jakarta: Erlangga.

Sears, David O. (1991). Psikologi Sosial, Edisi Kelima, Jilid I, Jakarta: Erlangga.

Sobur, Alex. (2003). Semiotika Komunikasi. Bandung: Remaja Rosda Karya.

Thompson, John B. (1995). Media and Modernity. California:Stanford University Press.

Thwaites, Tony dkk. (2002). Introducting Cultural and Media Studies, Sebuah Pendekatan Semiotik. Yogyakarta \& Bandung: Jalasutra.

Twitter Narcissism or Age-Old Communication. Diunduh Maret 2010 dari http://www. thefreelibrary.com/Twitter+narcissism.

Supersonic brain shredder. Ralph Nader. Jurnal Proquest. Forbes. New York: Nov 30, 1998. pg. 225, 2 pgs. Retrieved March 19, 2010, from ABI/INFORM Global. (Document ID: 36380148).

Ulas Kepribadian: Facebook dan Narsisme Kamis, 26 Februari 2009. Diunduh Maret 2010 dari http://ulasingkat.blogspot.com/2009/02/ulaskepribadian-facebook-dan narsisme.html. 